\title{
Fodbold som pædagogisk anliggende
}

\author{
af Knud Aage Nielsen
}

Fodbold i „,Parken“, fodbold i skolen, fodbold i klubben, fodbold i baggården og på gaden, fodbold $\mathrm{i}$ avisen, fodbold på TV -Danmarks nationalsport.

Hundredtusindvis af børn og voksne over det ganske land dyrker fodboldspillet og hvad dertil hører - som spillere, tilskuere, ledere, trænere, avisłæsere og TV-kiggere.

Medierne kappes om - på godt og ondt - at bringe de sidste nyheder om fodbold på alle niveauer, blandt andet fordi fodbolden er en væsentlig interesse - og påvirkningsfaktor i mange menneskers hverdag.

Denne udvikling medfører at fodbolden påkalder sig en øget interesse fra kredse uden for fodboldens verden. Jeg tænker på interesse fra sponsorer, politikere, forskere, psykologer og måske ikke mindst fra pædagoger.

Mange - måske især børn - er grebet af spillet og alt hvad der foregår omkring det i en sådan grad, at det beslaglægger deres tankevirksomhed i de fleste af ugens timer. Ikke blot når de spiller, men også når de snakker med deres kammerater - $\mathrm{i}$ frikvartererne, på vej til og fra skole, på vej til og fra kamp og i omklædningsrummet. Når de læser avisernes sportssider. Når de „,kun“ ser sport i TV. Når de taler med forældre og lærere. Når de drømmer om den næste kamp. Når de drømmer om en fodboldkarriere, o.s.v.

Det bliver fodboldpåvirkning i en stor del af ugens ,vågne timer". Der er tale om en uafbrudt påvirkning af disse menneskers udvikling - måden de tænker på, måden de omgås andre på, måden de tilpasser sig hverdagen på, kort sagt måden de angriber tilværelsen på.

Ikke underligt at sociologer, psykologer, pædagoger og andre, der interesserer sig for mennesker og menneskeligt samvær i større og større udstrækning, beskæftiger sig med disse påvirkninger, med spørgsmål som 
- hvad ligger der bag denne fascination?

- hvad kan fascinationen medføre?

- hvad er det for påvirkninger der foregår?

- hvordan og i hvilken grad påvirkes der?

- hvad kan disse påvirkninger føre til?

- hvilke normer og vaner indlæres?

- hvad er det, der opdrages til?

osv. osv.

Denne interesse for fodboldspillet i skole og fritid og for alt hvad fodbolden fører med sig af menneskelige og samfundsmæssige konsekvenser er ikke altid lige velkommen i fodboldkredse.

Mange fodboldledere og -trænere møder dette engagement med stor modstand og mistillid. Modviljen kan udtrykkes på mange måder. Hvem kender ikke spørgsmål og kommentarer som

- skal vi nu til at spille fodbold uden modstander?

- skal fodbold nu til at være et middel for pædagogerne?

- er fodbolden ikke god nok i sig selv?

- nu skal skolelærerne vel igen til at blande sig. osv. osv.

Et af de sidste udsagn i rækken kommer fra den professionelle fodboldtræner Niels Christian Holmstrøm. Han afslutter en to sider lang artikel $i$ „Tidsskrift for Idræt - august 1985“ med følgende kommentar: „Der er mange lærere - også seminarielærere - der ønsker et „opgør med sportificeringen i og uden for skolen ". Gid de må dø af intellektuel kedsomhed."

Det er da helt forståligt - men derfor ikke mere rimeligt - at alle de mennesker, som har levet og åndet for fodboldspillet $i$ et helt liv vil forsvare tingenes tilstand. Det er jo deres værk.

Imidlertid er fodbold ikke blot et fodboldanliggende - det har det for øvrigt aldrig været. Det er et samfundsanliggende, det er et politisk anliggende, det er pædagogisk anliggende osv. osv. Mulighederne for ,privatisering“ er svindende.

Ingen - som holder af dette dejlige spil - har haft til hensigt at ødelægge dets fascination f.eks. ved at afskaffe modstanderne eller lignende. Men det erefter min mening - nødvendigt at vi interesserer os for, hvordan denne "folkebevægelse" indgår i det samfund den er en del af, og hvordan fodboldarbejdet harmonerer med den måde livet $\mathrm{i}$ øvrigt leves på - kan leves på. 
Måske netop i en tid med „oplevet" succes

- hvor ,dansk" fodbold klarer sig fint internationalt.

- hvor fodbolden næsten hvert år fostrer eet talent, som kan klare sig $\mathrm{i}$ toppen af international fodbold.

- hvor klaphatte og andet karnevalsudstyr gør Danmark ære i udlandet.

- hvor fodboldlandsholdet og dets koryfæer har sat sig godt fast i folks bevidsthed - og ikke mindst i dagspressens.

- hvor sponsorerne står i kø for at være med.

er det vigtigt at stille sig spørgsmålet: „FODBOLD - AF HENSYN TIL HVEM?“

Jeg vil koncentrere mig om nogle af de pædagogiske spørgsmål, som jeg mener bør rejses i forbindelse med den udvikling fodbolden er inde i. F.eks.

- hvad er det, der går så godt?

- hvem er det, det går så godt for?

- hvad mener vi fodbolden skal være godt for?

- hvem mener vi fodbolden skal være god for?

- hvordan skal fodbolden foregå og hvorfor? osv. osv.

Efter min mening må vi - ud over den umiddelbare oplevelse, begejstring, hengivelse, glæde osv. - interessere os stærkt for ihvertfald følgende spørgsmål.

På dette område bliver der tale om den enkelte leders, træners, deltagers personlige vurdering og stillingtagen.

HVAD MENER VI DELTAGERNE FÅR UD AF AT SPILLE FODBOLD - ud over måske at lære at spille fodbold? (Det er trods alt kun et fătal, der kan leve af at spille fodbold).

HVAD SYNES VI DELTAGERNE SKAL HAVE UD AF AT SPILLE FODBOLD - ud over måske at lære at spille fodbold?

Drøftelse af, stillingtagen til og begrundelser for nogle svar på disse spørgsmål vil blive indholdet $\mathrm{i}$ det følgende.

I. HVAD FÅR DELTAGERNE UD AF AT SPILLE FODBOLD ud over måske at lære at spille fodbold? 


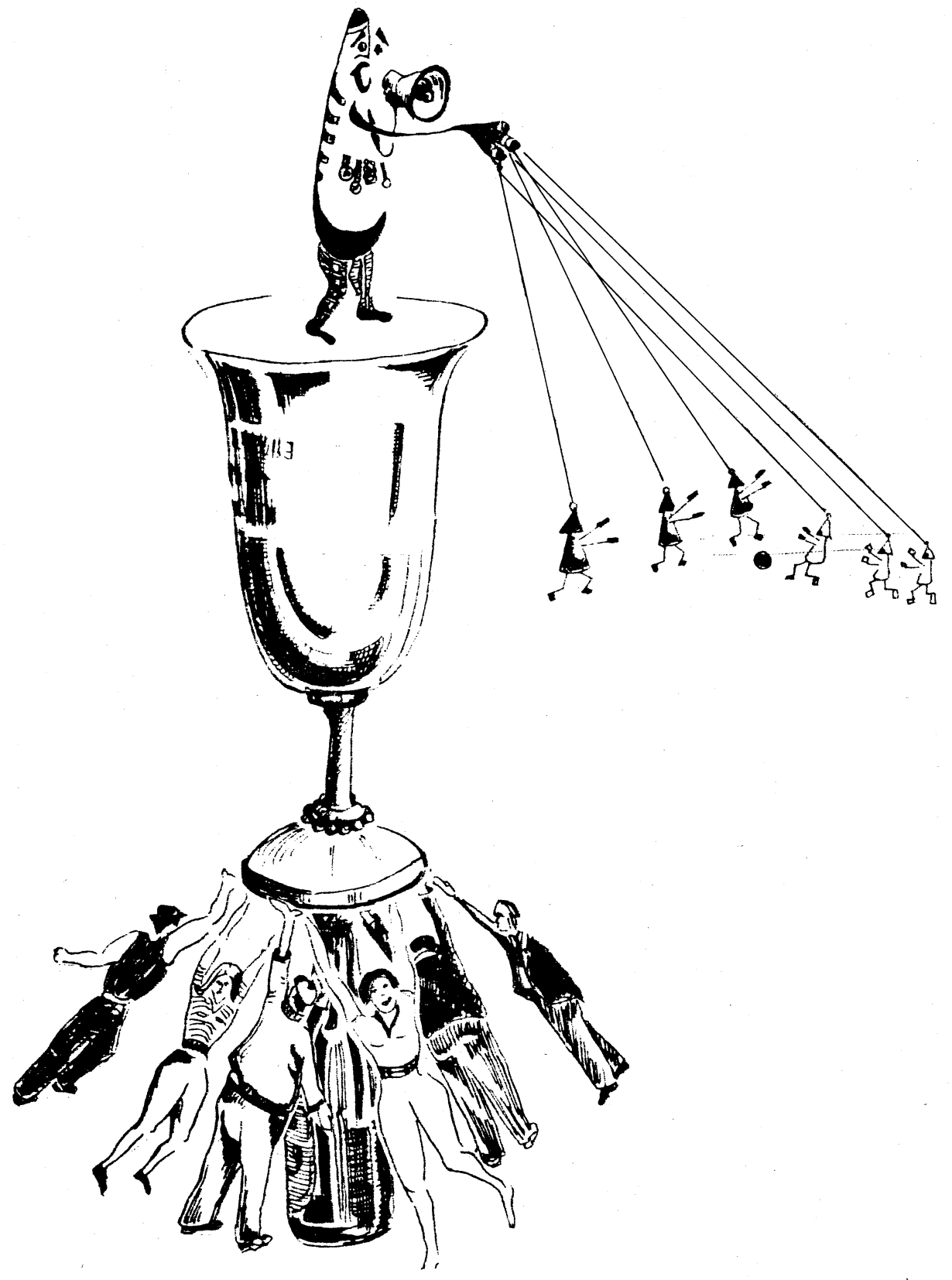


Normalt vil træningen foregå på den måde, at

TRAENEREN PÅ FORHÅND HAR FASTLAGT NOGLE MÅL FOR TRAENINGEN, SOM DANNER GRUNDLAG FOR PLANLFGNINGEN

TRAENEREN HAR UDVALGT ET TRAENINGSHOLD, SOM HAN/HUN MENER ER I OVERENSSTEMMELSE MED MÅLENE.

TRAENEREN BESLUTTER HVORDAN TRAENINGEN SKAL SAETTES I GANG OG FORLØBE, OG HVORDAN RESULTATET SKAL MÅLES.

En sådan form for træningsarbejde nyder stor anseelse. Den hviler på en grundlæggende - ofte ureflekteret - accept fra alle - forældre, klubledere, trænerkolleger og spillere. De ikke alene sætter pris på den stærkt styrende træning, de forlanger den.

Træneren bliver så eksperten, som stiler mod at videregive viden og udvikle færdigheder med størst mulig sikkerhed og effekt.

Kampen - ugens højdepunkt - afvikles med tilsvarende styring

- lederne har fastlagt turneringsplanen.

- lederne har sørget for at banen er streget op.

- lederne har sørget for at trøjerne er vasket og støvlerne eventuelt pudsede.

- lederne har sørget for penge til og bestilling af transport, hvis der er tale om udekamp.

- lederne har fastsat afgangstidspunkt.

- lederne sørger for at udfylde holdkort og betale dommer. osv. osv.

- træneren sørger for at stille hold.

- træneren sørger for at spillerne bliver varmet op.

- træneren sørger for at lægge taktikken.

- træneren sørger for at spillerne forstår den lagte taktik.

- træneren sørger for at skifte ud, hvis han synes, det er nødvendigt. osv. osv. 
F.eks.

1. At de skal høre efter og gøre hvad der bliver sagt.

2. At de skal løse de opgaver, de får tildelt, og ikke mere.

3. At de der er sat til at lede bestemmer.

4. At man skal tilpasse sig de tilbud man får.

5. At det er vigtigt at være passiv modtagende.

6. At hele ansvaret bør ligge hos andre.

7. At klubben er en serviceinstitution.

8. At man kan forlange, at andre tager sig af alt andet, end det at spille.

9. At man har lov til at forbruge andres tid når man betaler kontingent.

10. fortsæt selv.

Allerede $\mathrm{i}$ en tidlig alder stifter børnene bekendtskab med disse styringsformer, hvis de interesserer sig for fodbold, og det gør de fleste på et eller andet tidspunkt af deres liv.

Lad mig give et - måske polemisk - eksempel.

Hans er 7 år og interesseret $\mathrm{i}$ at spille fodbold. Han bliver meldt ind $\mathrm{i}$ en klub og bliver deltager i en såkaldt interessegruppe.

\section{NU FANGER SYSTEMET}

Hans får besked på:

- hvor mange gange om ugen han er interesseret $\mathrm{i}$ at træne

- at han er interesseret $i$ at træne med nogle som er på samme alder som han.

- at han er interesseret $\mathrm{i}$ at spille $\mathrm{i}$ en trøje, der reklamerer for pølsemanden

- at han er interesseret $\mathrm{i}$ at spille kamp de fleste søndage

- at han er interesseret $i$ at spille højre back

- at han næste søndag er interesseret $i$ at blive sat af osv. Osv.

Sådanne ledelsesmetoder medfører let, at deltagerne føler sig magtesløse i miljøet, men idrætsarbejdets traditioner, normer og myter er åbenbart så autoriserede og stærke, at det muliggør praktisering af ledelsesformer, som ville være aldeles utænkelige $i$ andre situationer.

Jeg tænker f.eks. på: 
- at man tillader sig at bruge de aktives arbejde til tilfredsstillelse af egne behov - trænerens, klubbens, forbundets.

- at man tillader sig at plan- og tilrettelægge arbejdet hen over hovedet på deltagerne.

- at man tillader at produktet (to points, mesterskab, klubbens ære osv.) tager herredømmet over deltagerne.

Man kan undre sig over, at de fleste idrætsudøvere og ledere - $i$ vort demokratiske samfund - betragter dette som selvfølgeligheder. De lader sig villigt styre af udefra og ovenfra kommende interesser, og af normer, som er $\mathrm{i}$ modstrid med ganske almindelige demokratiske rettigheder.

Fodboldledere og trænere er hårdt belastede arbejdsmæssigt, der er jo tale om fritidsjob. Der bliver ikke tid til at drøfte overordnede intentioner. De tvinges derfor til at handle rutinemæssigt. Det bliver nærliggende at plagiere de største fodboldeksperter, selv om disse eksperter og deres spillere har helt andre forudsætninger, behov og muligheder.

Derved bliver normer, arbejdsmetoder og adfærd ofte kritikløst overført fra topfodbold til fodboldarbejdet som helhed, hvilket $i$ allerhøjeste grad er uhensigtsmæssigt.

Almindelige demokratiske adfærdsnormer bør naturligvis indgå i træning og opdragelse af børn. Kvaliteter som medansvarlighed, tolerance, lydhørhed over for andre synspunkter, frimodighed, tillidsfuldhed og omsorg må vurderes som nødvendige forudsætninger for et tvangfrit interessebetonet samvær. Det kunne være godt for fodboldledere og -trænere af og til at vurdere i hvilken udstrækning deres arbejde lever op til sådanne kvaliteter.

II. HVAD SYNES VI DELTAGERNE SKAL HAVE UD AF AT SPILLE FODBOLD ud over måske at lære at spille fodbold?

(Her kommer - af gode grunde - mine subjektive svar på spørgsmålet.)

Det fodboldarbejde jeg har beskrevet under afsnit I må efter min mening ændres radikalt.

Arbejdet må foregå på en måde, så deltagerne har indsigt i og indflydelse på de overvejelser, der fører frem til den træning de skal deltage i. Det vil betyde, at de hele tiden kan være med til at analysere, vurdere og ændre på træningen, så den lever op til de hensigter, man har med den. 
ALTSÅ

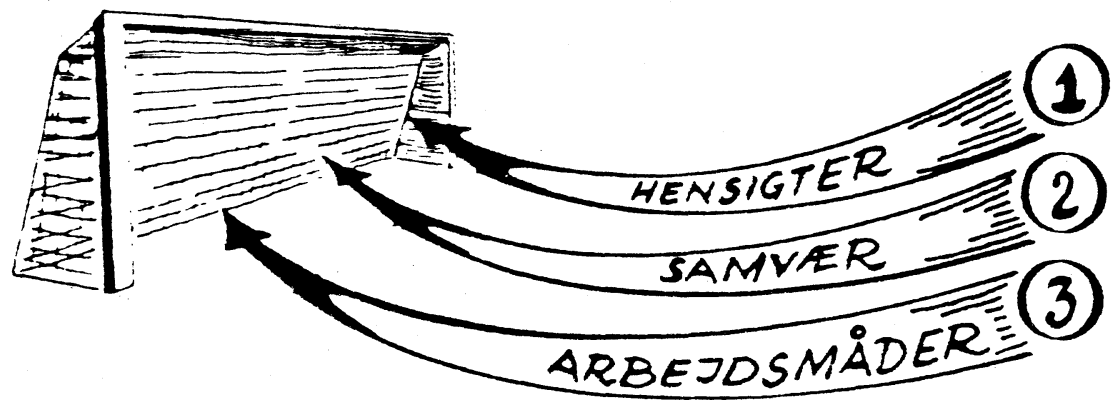

Der skal være tale om fælles beslutninger både om hensigterne, om hvordan samværet skal være og om hvordan arbejdet skal foregå. Træningen må styres af fællesbeslutninger på tre områder:

1. Hensigterne - der må præges af

- bestræbelser på at gøre deltagerne aktive og medansvarlige.

- ikke blot at være til for fodboldspillets skyld, men nok så meget for deltagernes.

- at vedkende sig opdragende, pædagogiske og udviklende opgaver.

- et engagement i det, der sker mellem mennesker.

2. Samværet må være kendetegnet ved

- en aldrig svigtende åbenhed over for forskellige synspunkter.

- en vilje til at tage synspunkterne højtideligt $i$ en herredømmefri drøftelse.

3. Arbejdsmåderne må være karakteriseret ved

- at der tages udgangspunkt $\mathrm{i}$ deltagernes erfaringer/fælleserfaringer, forventninger og behov.

- at de i høj grad lægger op til samarbejde.

Kampene og deres afvikling må være et fællesanliggende. 
Sæsonplanen gennemdrøftes og man tager stilling til

- hvem sørger for vask af tøj i hvilken periode?

- hvem har ansvaret for transport til hvilke kampe?

- hvilken transport er der råd til?

- hvem sørger for holdkort?

- hvem betaler dommer? osv. osv.

- hvordan kan den enkelte spiller sikre sig at han/hun er tilstrækkeligt opvarmet inden kampen?

- hvor lang tid før kampen skal vi mødes for at sikre, at også de der er langsomme startere når at få varmet op?

- på hvilken tid af ugen er det mest hensigtsmæssigt at drøfte taktikken til den næste kamp?

- hvordan bærer vi os bedst ad med at få fordelt arbejdsopgaverne på banen til den næste kamp?

osv. osv.

\section{OG HVAD KAN MAN SÅ LERE AF DET?}

F.eks.

1. At en fodboldklub er et fællesanliggende - ikke en serviceinstitution. (helseinstitut).

2. At der er sammenhæng mellem at yde og at nyde.

3. At samarbejde må hvile på fællesbeslutninger.

4. At fælles hensigter er nødvendige, hvis man skal kunne handle ansvarligt.

5. At fælles beslutninger og solidaritet og ansvarlighed med hensyn til deres gennemførelse er af vital betydning både $\mathrm{i}$ fodbold og i tilværelsen i øvrigt.

- fortsæt selv.

\section{HVORFOR ÆENDRE PÅ DEN MÅDE FODBOLDARBEJDET FOREGÅR PÅ?}

Hvilken tilværelse ønsker vi for os selv og andre? - Og hvordan svarer virkeligheden til ønskerne? - Det er spørgsmål som har optaget mange altid, velsagtens - men ikke mindst i de seneste år. Og uanset om de, som overvejer, er kunstnere eller samfundsforskere, pædagoger eller organisationsfolk, kommer de oftest til samme resultat: Virkeligheden er præget af en opsplitning, som tiltager og breder sig til stadig flere livsområder - mens ønskerne omvendt retter sig mod at opleve helhed og sammenhæng. 
Opsplitning er en gammel historie inden for produktionsprocesserne, vokset frem med industrialiseringen. Opdeling i specialiserede delprocesser blev midlet til rationalisering af produktionen (jvf. fodboldarbejdet). Derfor hører opsplitningen også nøje sammen med tidsstudier. Tid blev penge.

Det er $\mathrm{i}$ nyere historie, at opsplitningen og tidsstyringen bredte sig til fritidslivet og familielivet og til de ikke erhvervsaktive ældres og unges liv.

Det har med forbrugstilbuddene at gøre: Private og offentlige kræfter sættes ind på at give tilbud i fritiden. Mulighederne er mange, men de er alle struktureret og tilrettelagt forud af andre. De tilbyder underholdning, som kan modtages passivt eller aktivt inden for meget nøje afstukne rammer og tidsrum. De får derfor karakter af forbrug, mere end af selvstændig livsudfoldelse.

Og det har at gøre med, at institutioner overtager flere og flere opgaver: Børn anbringes i vuggestuer, børnehaver, fritidshjem m.m. Syge og gamle samles på andre institutioner. Og alle institutioner har ledere, plejere osv.

I fritiden som $i$ arbejdssituationen fører opsplitningen til, at man gøres uselvstændig. Ligesom man arbejder under andres ledelse, forbruger man også sin fritid på andres betingelser.

For børn og unge betyder dette, at de vokser op $i$ et kulturelt tomrum - tomt for kulturel tradition og mening, men opfyldt af et masseudbud af muligheder for forbrug.

Børns tid er opdelt og styret. De transporteres på bestemte klokkeslet fra hjem til børnehave eller skole, videre til fritidshjem, til musikundervisning, til spejder, sport, danseskole og klub. Finder nogle børn på selv at udfolde spontan aktivitet - breakdance til en båndoptager på torvet - er danseinstituttet overfor straks klar med et tilbud: Her kan I lære breakdance under instruktion, mod betaling, tirsdag og fredag kl. 16-17.

Og mængden af fritid vokser. For mange - og især mange unge - drejer det sig om uønsket og ufrivilligt påført fritid, også kaldet ledighed. Hvad kan de bruge den tid til?

De mangler nogle muligheder, som tidligere generationer har haft. De har ringe muligheder for at indgå i fællesskaber, sammen med voksne og sammen med hinanden - fællesskaber med god tid og udfoldelse på egne betinge/ser - hvor de kunne orientere sig, gøre erfaringer og danne sig værdiopfattelser sammen med andre.

De har ringe lejlighed til at opleve sig som aktive, medansvarlige og medbestemmende over for deres egen og samfundets nutid og fremtid. De har ringe mulighed for at opleve, at nogen har brug for dem, og at deres liv har indhold og mening.

Vi ser unge reagere meget forskelligt $i$ denne situation. Mange finder sig til 
rette og udnytter forbrugermulighederne. Mange griber til alkohol og narkotika som mulighed for at hæve sig over tomheden. Mange bryder ud og søger sammen i alternative fællesskaber - kollektiver, bofællesskaber.

De mest yderliggående reaktioner ser vi hos rockere og BZ-ere. Vi kan have svært ved at forstå dem. Men det er tydeligt, at de hver på deres måde søger at opbygge nære sammenhænge med klare fælles værdier. Og det er tydeligt, at de tager afstand fra alt, hvad samfundet og de voksne står for og kan tilbyde.

Det kan ikke nytte, at man fortsat udstyrer undervisere med formynderroller og stiler mod det størst mulige serviceniveau over for børn og unge i hele deres opvækst, at man sætter eksperter til at made, passe, opbevare, underholde, opdrage, irettesætte og koste rundt med dem (,,sig fodbold").

Det kunne måske forsvares - dog ikke af $\mathrm{mig}-\mathrm{i}$ en tid hvor alle de unge havde udsigt til et arbejde med løn, og dermed muligheder for at opleve de normer, der ligger $i$ en sådan opdragelse anvendelige $i$ deres lønarbejdertilværelse, samt at lønnen kunne finansiere et fortsat højt serviceniveau.

Men når man fremturer med at opdrage børn og unge til at lade sig styre af eksperter, som beslaglægger deres tid, giver den indhold og hele tiden anbringer dem i modtagerens rolle (,,sig fodbold") - selv om man ved, at en stor del af dem går ud til en tilværelse hvor de selv bliver nødt til at administrere døgnets 24 timer -SÅ ER DET BEDRAGERI.

Den kommende generation får om muligt endnu større behov for at vurdere, tage stilling, beslutte, handle og tage konsekvenser, end den nuværende har haft. DE MÅ LÆERE AT STILLE SPØRGSMÅL, IKKE ALTID AT GIVE SVAR.

Vi får i fremtiden masser af menneskelige ressourcer som ikke trænger til at blive passiviseret - men til at blive brugt. Vi får brug for aktiv handlen - $i$ vort nære liv under de givne betingelser og $i$ det langsomme og besværlige arbejde med at ændre betingelserne f.eks. $i$ det eksisterende fodboldliv.

Vi må skridt for skridt tilbageerobre de livsområder som stat, kommuner, organisationer, foreninger og andre formyndere har eksproprieret. Det må kendetegne hverdagen - også når vi spiller fodbold - at vi fordrer, dels at få indsigt i de beslutninger, der direkte eller indirekte berører os, dels médindflydelse, når disse beslutninger tages. 
Vi må kræve:

AT FÅ LOV AT VAERE ANSVARLIGE.

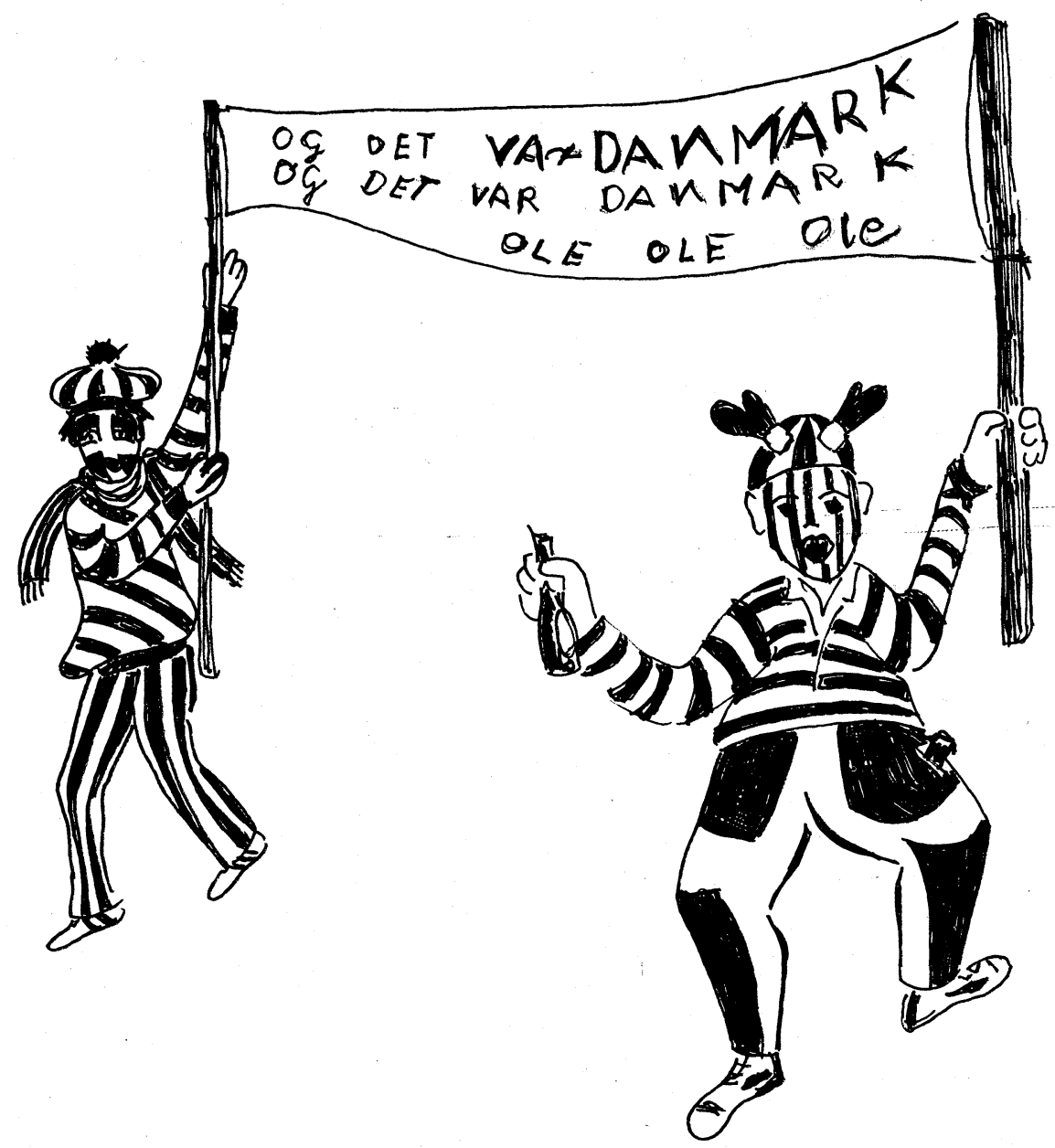

\section{Litteratur:}

Boldspilundervisning - nogle synspunkter. Knud Aage Nielsen, Forlaget DUO. Med venlig hilsen. Kolding Seminarium. 